\title{
Panji in Javanese court literature and beyond
}

\author{
ANN KUMAR
}

\begin{abstract}
This article deals with Panji stories from Java, their original home. It begins with an examination of Panji as he appears in the Wangbay Wideya, one of the earliest extant Panji stories, representing the culture of Majapahit and its successor states. It then goes on to survey a number of Panji compositions written by Pakubuwana IV, Sunan of Surakarta from 1788-1820, which reveal that Pakubuwana clearly identified with Panji, as opposed to say, Islamic models, or Western models, for the political realm possibly available at that time. The article goes on to look at the somewhat later writings of Yasadipura II (1756-1844) and Dipanagara, who led the 1825-1830 Java War against the Dutch. The former has a markedly bureaucratic, non-mythic approach to government. The latter does draw heavily on mythic validation, for instance from indigenous Javanese deities and from Islamic figures, but here too there is a notable lack of reference to Panji as an ideal. Panji theatre across Java and at the popular level is briefly surveyed, as is the extensive export of Panji stories to Malaysia, mainland Southeast Asia, and even possibly to Japan - which would suggest that they are far older than hitherto suspected.
\end{abstract}

KEYWORDS

Heroic epics; Majapahit; Pakubuwana IV; governance; Yasadipura II; Dipanagara.

ANN KUMAR is Emeritus Professor and a professional historian with expertise in Indonesian, especially Javanese, history up until the nineteenth century, and Islam. She taught at the Australian National University for 40 years, where she was Head of the Department of Asian History and Civilizations and Dean of the Faculty of Asian Studies. She has served as VicePresident of the Australian Academy of the Humanities, and is an Honorary Research Professor of the Nordic Institute of Asian Studies. Most recently she served on the panel of experts of the British Library's Endangered Archives Programme. She holds the Dutch Ministry of Education and Sciences medal and the Australian Centenary Medal. She prefers to focus on those questions of (pre-) history which can be quantified, for example the use of DNA and linguistics for the history of societies lacking extensive written records. She is perhaps best known for her work on the warrior women of the Javanese courts, and previously unknown ancient links between Java with Japan. Her website http://dna-warrior-woman.net gives more extensive details. Ann Kumar can be reached at: ann.kumar@anu.edu.au. 


\section{INTRODUCTORY NOTE}

This paper represents a modest attempt to survey some of the surviving exemplars of the Panji stories found in their place of origin, Java, investigating their literary, social and/or political significance over a long period. It also briefly outlines the remarkable spread of the Panji stories across Southeast Asia and even East Asia, revealing their great attraction, over millenia, to numerous royal courts and their followers.

\section{A. Panji in Javanese court literature}

1. The original PANJI

What are the origins of the Panji stories? Rassers (1959) has proposed an answer to this question in suggesting that they arose in and reflect a tribal society with two phratries. We have no evidence that Panji stories originated in tribal society. The first surviving Javanese Panji stories come from a wellestablished court society, profoundly influenced by Indic religion and culture. Evidence from quite a different part of Asia, however, suggests that the Panji stories as a portrayal of and advertisement for the royal court (rather than a tribal society) are very old, perhaps going back to the first millennium B.C. ${ }^{1}$

\section{Hinduized Royal Panji}

For this period, I have used the Middle Javanese text, Wangbay Wideya (S.O. Robson 1971), which may be seen as reflecting the court civilization of Indianized, pre-Islamic, Javanese courts. It reveals quite a lot about the formation of future monarchs at this period.

At the beginning of the work, reference is made to the central theme of the Panji romances, the hero's quest to find his beloved, who has unaccountably disappeared. Panji is described as furious, impelling him to attack all the villages, hermitages, and other places in every country through which he passes (Robson 1971: 59).

His martial prowess has the effect that he wins wives as tokens of submission (Robson 1971: 61). But he is no rough soldier. The author describes in detail his splendid attire on various occasions, on one of which he was wearing a wastra, traditional (hand-crafted) textile, with designs of two kinds of flowers, a sash of white imar $^{2}$ cloth and a head-cloth of green embroidered with gold (Robson 1971: 63). His attire consists of a wastra with a design of two kinds of flowers, a sash of white limar cloth and a head-cloth of green embroidered with gold (Robson 1971: 63). On another occasion, he wears a wastra of fine design with a smart tumpal ${ }^{3}$ motif in white, and his kris has a handle in the form of Buta Sancayasari and a sheath painted with the deity of the flowers. He wears fragrant unguent and an ornamented dosa flower behind his ear (Robson 1971: 183). His kris is inlaid with a scene from the lakon Gatotkacasraya (Robson 1971: 95).

\footnotetext{
1 See further Section B "Panji overseas".

2 'A kind of silk' (Zoetmulder 1982: 1029).

3 'Edge, border (of a garment, of another colour)' (Zoetmulder 1982: 2061).
} 
Nor is he just a dandy: his musicianship is outstanding: for instance, he excels all others in playing the samepa, melody Smarantaka (Robson 1971: 73). He is equally proficient as a dalang of the wayang, performing the lakon Jinawikrama with consummate skill (Robson 1971: 95). In a later passage, the scene where Arjuna is speaking soft words to Dewi Supraba causes the audience to be smitten with love. He used the Sanskrit words faultlessly, and was clearly an expert in the sacred books (Robson 1971: 186-187).

And he is an artist: he is depicted painting a pattern to be embroidered by his beloved (Robson 1971: 99). The ruler says that it is unequalled in elegance, and seems as if it cannot be the work of a man (Robson 1971:101). His beloved embroiders it (Robson 1971: 105), and this display of skills by the hero and heroine is repeated later (Robson 1971: 187). Though the description of the courtship of the hero and his beloved is charged with eroticism, they are also depicted as possessing artistic skills not easy to acquire. At one juncture, Panji uses stencil and ink to produce a drawing on a white $k a m p u h^{4}$ which his beloved has to embroider - at a royal audience.

Panji is also a poet, writing a poem to his beloved on a flower bud (Robson 1971: 105). In contrast to the opening passage portrayal of him as a fierce, even ruthless warrior, Panji is later described as discerning, knowledgeable in letters, unselfish in thought and policy, considerate of the inmost feelings of others, generous to the poor, giving shade to those affected by heat, and inspiring the devotion of the leading brahmans. In addition, he is daring enough to deal with someone running amuck (Robson 1971: 113).

Returning to the theme of the opening passage, he is later depicted as a glorious leader in battle, leading the battle array seated on an elephant (Robson 1971: 125). He carries out a ceremonial Battle Sacrifice to the Lord Siwa in order to achieve victory or a glorious death (Robson 1971: 133). Later, he is described as nimbly dodging and thrusting like Hanuman (Robson 1971: 141). After he completely destroys the enemy, the king feels that he is like a god in warrior form, sent down from heaven, and a ceremonial salute is given him (Robson 1971: 155).

Yet shortly after this ferocious battle in which his strength and skill triumphed, he is depicted as a man of unusual sensibility: at one point, people fear he will die of heartbreak, lying face down on his beloved's cast-off clothes (Robson 1971: 179). Further, he is described as virtuous, unassuming and gentle (Robson 1971: 181).

To sum up, Panji has an extraordinary range of military capabilities, including on occasion ruthlessness, even to the innocent, but also far more civilized qualities such as learning, literary and artistic skills, and romantic sensibility - truly a man for all seasons, not just any great warrior but an exceptionally erudite and artistic one.

All this suggests that the Wangbay Wideya is simply hyperbole and exaggeration. But we must remember that Java actually was a place of

\footnotetext{
4 'A fine ceremonial kain' (Robson 1971: 75) or 'garment worn around the lower part of the
} body (see also wastra)' (Zoetmulder 1982: 787). 
extraordinary art, sculpture, metalworking, jewellery and weapon-making technology - which extraordinary accomplishments motivated the spread of the Panji stories outside Java ${ }^{5}$ - so from this point of view Wangbay Wideya is not quite as hyperbolic as it seems. What remains improbable of course is that one man could possess all these skills, and film-star-like qualities as well. But that this was the ideal indicates that Java at this time had a desideratum for upper-class qualities very like that of Renaissance Italy, in its combination of cultivation with outstanding martial prowess.

\section{The Panji ideal in the Self-Presentation of A Javanese Ruler}

After the wars of the mid eighteenth century, the Dutch divided the kingdom of Mataram into two larger principalities, the Sultanate of Yogyakarta and the Sunanate of Surakarta, plus two smaller ones, the Mangkunegaran and the Pakualaman.

The ruler of Surakarta from 1788-1820, Pakubuwana IV, was a serious devotee of Panji, writing numerous Panji works and also dressing as Panji in court dance dramas.

His Panji works are set in a wider world than that of Wangbay Wideya. In particular, he seems to have been considerably preoccupied with the aggressive Makassarese, who play a major role in three of his compositions that were probably wayang gedhog lakons, namely Panji Dadap, Panji Raras, and Panji Sekar, ${ }^{6}$ outlined below. The long complex plots, the drama and comic relief scenes, and the frequent occurrence of characters in disguise, whose real identity the audience could take pleasure in discovering, seem more likely to be intended for performance than reading. ${ }^{7}$

\section{The PANJI IDEAL ${ }^{8}$}

\section{Canto I}

The work is said to be a cerita wayang (wayang story) consisting of three lakon. It starts out with a group of kings who have been defeated in war by a king who takes the form of a snake. Prabu Bramasekti is talking to his ananda prabu Makassar asking him to agree to seek help from Jambi, whose king is extremely sakti (having supernatural powers) and unbeatable.

The scene changes to a hutan (forest) where Panji and his faithful adik (younger brother), Panji Carangwaspa are located. A kuntum (bud) of white flower is seen in the jungle, which is called Lara Kendat. It calls Panji, and he tells his adik, who does not believe him. The flower tells Panji that she was formerly a human noblewoman who had an ill-starred love for Begawan Palasara, who married someone else. She hanged herself, but turned into a flower. Begawan Palasara, who is one of Panji's ancestors, lost his wife

\footnotetext{
${ }^{5}$ See further Section B "Panji overseas".

${ }^{6}$ See Nancy Florida (1993: 155).

7 On Panji dances, see further Clara Brakel-Papenhuyzen (1992: 3-22, 1993).

8 Panji Dadap 1980.
} 
to the ascete resi Sentanu. Lara Kendat asks Panji to release her from being imprisoned as a flower, which he does by semadi (meditation) and heningkan cipta (quietening the consciousness). In return, she cures him of the venereal disease (sakit asmara) from which he has been suffering. Because of this Panji is called Kelana Jayeng Sekar ('wanderer victorious over the flower'). Panji Carangwaspa doesn't realize that Panji has been cured but Bancak Doyok [apparently a comic panakawan type] does. Panji brings his adik up to date, and the latter respectfully suggests they now think about the situation of Dewi Sekartaji.

\section{Canto II}

A goddess called Dewi Kenakawulan is flying over the jungle. She sees Panji and Panji Muda (Carangwaspa) and is impressed by their wibawa (majestic appearance), etcetera. Introduces herself to the latter as the daughter of an abdi kasar/putut (a common servant/hermit's follower or student), which he rather doubts as she is so incredibly beautiful. He is hopelessly smitten. They engage in a contest of shooting arrows at each other (she has the arrows Saradula and Rodrasarpa, the latter especially poisonous). He wins the contest and she decides to study under him.

\section{Canto III}

Panji Carangwaspa is enamoured of Dewi Kenakawulan and kisses her. She reproaches him for his un-satria (un-chivalrous) like behaviour and says that this violent and inappropriate approach is unacceptable to her, even though she is only someone from the mountains, the child of a miserable cantrik (the student of a guru). She requires the marriage rites according to the adat of kings, with sacrifices of an ocean of blood, and an island inhabited by horses and elephants with all flags flying [sic, page 22 Stanza 3]. She then flies off into the firmament. Panji Carangwaspa (also known as Panji Jungut and Panji Muda) is terribly upset, and expresses his feelings in poetry. Panji Tua then wakes from his sleep and finds his adik. He too reproaches him for his shaming behaviour, unbefitting the descendant of kings. Enter Bancak and Doyok to help things along.

\section{Canto IV}

For some reason, they know where to find Dewi Kenakawulan. She has returned to her extremely beautiful and well ornamented pesanggrahan at the foot of the mountain (described in detail). She has 400 prajurit estri ${ }^{9}$ attending her, as well as prajurit pria. The female ones are divided into groups of 100, all wearing the same uniform. These are extremely fine, of silk, they wear gelang and badong, gold ikat pinggang, and crowns in Garuda form with shining diamonds. They are all courageous and skilled in cavalry warfare.

\footnotetext{
9 This was a court practice in Surakarta, notably at the Mangkunegaran: see Ann Kumar (1980: 30, Stanza 8).
} 
When Bancak and Doyok arrive there is dancing going on, accompanied by gamelan, with a dance representing heavenly nymphs (bidadari). Sang Retna Kenakawulan is particularly beautiful and Panji Carangwaspa recognizes her. A seduction scene follows, after which they swear fidelity to each other.

\section{Canto V}

\section{Prabu Suryadadwa comes to visit his adik Dewi Kenakawulan}

He is prevented from seeing her by Ki Doyok who tells him that Dewi Kenakawulan has a visitor. When he resists he is subdued and tied up. He accuses his adik of behaving shamefully, like a dog, or a whore who should be cut into pieces. All is sorted out, and the king eventually comes to love Panji Muda, and swears to defend Panji who is in the jungle. Dewi Kenakawulan leaves for Dadapan, where it is known that Retna Galuh [namely Sekartaji, Candrakirana] is to be found, together with Retna Ragilkuning.

\section{Canto VI}

\section{Sang Panji Wanengpati meets Dewi Sekartaji}

Panji and Bancak go through the jungle and come upon a gold-ornamented gapura. It is the dwelling of a Resi, who is attended by monkeys who can communicate like humans. He is angry with Panji whom he accuses of membuat kotoran (making a mess) and sinning unforgivably. Then he departs for the heavenly abode of the goods. Panji and Bancak go to Dadapan. The meeting of the prince and princess is heralded by gentle winds spreading fragrance, from bidadari who fill the sky. Their radiance illumines the garden because they fly low, some even landing. Birds sing, joining in the prayer that all the huru-hara (uproar) in the world should disappear. There is a long description of the touching meeting between Panji and Candrakirana, and also Panji and Ragilkuning. Ki Jangkung is also present, and there is some horseplay.

\section{Canto VII}

Prabu Surya Dadwa and Dewi Kenakawulan and Panji Muda go back to Manggada where the king assembles troops to help his adik against the enemy kings. The spies of the latter find out. The king of Manila suggests a preemptive strike as it will be more difficult if all their enemies gather in Jenggala. The king of Makassar agrees. The Makassar army has 4,000 cavalrymen with swords and 30,000 troops. They attack and burn the Manggada pasanggrahan. The Patih of Manggada puts up a heroic defence fierce fighting etcetera, but Manggada gets the worst of it.

\section{Canto VIII}

It seems that the king of Manggada had gone on ahead. He now gets news of the defeat of his troops who were left holding the fort. He gets his adik, Dewi Kenakawulan, to fly back and help them. She has Bramastra arrows which give out fire, producing a rain of fire on the enemy forces. She is later joined by 
her brother the king and her husband Panji Carangwaspa. The strategy of the enemy king to put out fire by producing rain fails when Dewi Kenakawulan produces wind to disperse the rain; she also has another sakti weapon, the Cakra, which is a pusaka ${ }^{10}$ of the Makassar kraton captured by her. Defeat of the enemy kings, who give order for their forces to withdraw.

\section{Canto IX}

Prabu Suryadadwa together with Panji Carangwaspa and his wife Dewi Kenakawulan set off to appear before Panji

The Bramastra arrows return, the party sets out. Meanwhile in the Taman Sari Panji and his wife are sitting amorously together, when Ni Dadapan comes to announce the arrival of an armed force: a chariot drawn by large horses followed by 400 cavalry. She fears it is a hostile force. She notes however that the person in front riding an elephant looks like Doyok, though he is wearing glittering clothes, with jamang (diadem or head ornament), kelat bau (bracelet worn around the upper-arm), and diamonds. Panji asks Bancak if this could really be his adik, and Bancak says that he will pull him off and throw him into the mud for his pretensions. The envoys come before Panji and are overawed by the moonlike radiance of his face. The envoys explain about the marriage of Dewi Kenakawulan with Panji Carangwaspa. Panji is pleased and asks that the three main persons be shown in, but without a whole army. Prabu Suryadadwa has a selir (concubine) with him, the head of the putri (princess) from Tasikwilis, who is acting as his queen. She is leading six other selir! Panji tells his queen and Ni Dadapan and Ragilkuning, who are all pleased. When the party arrives Bancak gets up on the elephant and seizes Doyok's ear, taking off his jamang and kalung. He falls off, they wrestle, laugh uproariously etcetera. The king bows before Panji. Various people hold hands with each other. Ragilkuning shakes hands with Dewi Kenakawulan and laughs loudly, saying: my beauty I hardly recognized you, you have married a tall thin satria. She pinches her, remembering times when they have joked together. Eight heads of the prajurit estri are invited in to join the celebrations. Food is served. Then Panji tells his adik the king of Manggada to send a letter to the king of Kediri letting him know developments. Suryadadwa replies that he will send his Patih to let them know Panji has been reunited with his queen; it is also agreed to let him know About Panji Carangwaspa's marriage with Dewi Kenakawulan. Bancak asks that he and Doyok should be in the letter, but Doyok says this is inappropriate pretension, it is up to the wishes of the Gusti. Panji smiles and asks his adik (the king of Manggada) to put these two people into the letter.

10 '(Revered or sacred) heirloom'. 
PANJI RARAS ${ }^{11}$

\section{Pakubuwana IV's "Panji Raras" also centres around the Makassarese}

The story has two main elements: Panji's wife, Retna Galuh Sekartaji, has been falsely accused of infidelity and intends to kill herself. The gods, namely Batara Surya under the orders of Batara Guru, intervene to prevent this and plant a simulacrum corpse with a kris stuck in it. The second element is the attack of the enemies, actually Makassarese, who take advantage of Panji's sorrow over the (apparent) death of his wife. The Kediri forces are helped by Resi Andakara. Dewi Onengan disappears, and Panji and his brother Panji Carangwaspa go in search of her. They are attacked by enemies and though Panji Carangwaspa fights like ten men they are overwhelmed and bound and captured. The gods Batara Basuki and Batara Sramba help them. They are released and the enemies retreat. A character called Randha Dhadhapan is given two female cats by a pendeta (priest) and told to look after them, which will bring her much good fortune. She now has much greater success in her occupation of looking for leaves in the jungle, and also the two cats transform themselves into beautiful, and highly useful, young women while she is out at work. They clean the house, cook, etcetera. They are actually Dewi Ragilkuning (namely Onengan?) and Dewi Candrakirana - the latter teaches the former much secret knowledge. Randha Dhadhapan hides herself to find out who is doing all this. When she discovers the beautiful young women, she calls them Limaran (Candrakirana) and Silakatangi (Onengan). They also weave and do batik. They get pusaka tusuk gelung [sanggul, namely chignon fasteners] from Resi Andakara, and Limaran gets the pusaka Cundhuk Cundhamani from Dewi Wilutama, while Silakatangi gets a cundhuk ${ }^{12}$ from Batara Guru. These cundhuks are bertuah (magically potent).

The enemy kings Bramakumara and Suryadadwa send the latter's younger sister Retna Kenakasasi (in siluman/disguise form) to kidnap these two wonderful young women. Sekartaji is suspicious. Kenakasasi's attacks are however nullified by the magical cundhuk. She turns into a snake. Dewi Sekartaji copes with this too. Kings from other countries are also interested in these young women. They are chased away by the snake. Kenakasasi is still trying to get the young women, and is again foiled by Dewi Sekartaji. Finally, she gives in and asks for pardon. As a reward for her repentance, she is now to marry Panji Carangwaspa.

The Makassarese also provide the motivation for another of his compositions, Panji Sekar. ${ }^{13}$ These centres around attacks by Raja Bramakumara of Makassar and the Bala Tentara of Sabrang, which are defeated by Panji. Dewi Sekar Taji again plays a significant role.

It will be seen that Pakubuwana II's Panji stories differ greatly from Wangbay Wideya. They are much more involved, and they do not give the same importance to learning and accomplishment. Typically, Javanese characters

\footnotetext{
${ }^{11}$ See Panji Raras 1978.

12 'Ornament for the hair, often in the shape of a flower'.

${ }^{13}$ Panji Sekar 1979.
} 
such as the "comic servant" type, have made an appearance. They are outright fantasies relating supernatural events, and there is a liberal measure of the erotic and the humorous.

A somewhat different picture emerges from the account of Panji's armed assault not on Makassar but on Bali ${ }^{14}$ summarized below.

This is a story of the forces of Ngurawan attacking Bali. Other subordinate adipati (governors/military commanders) from Gembong, Pasuruhan, Japan, Prabalingga, Bangil, and Pajarakan, are also taking part. ${ }^{15}$

One of the commanders, called Ki Kelana, is married to a putri from Cemara called Dewi Surengrana who is not only as beautiful as the widadari Wilutama but also an outstanding warrior in charge of 800 men. ${ }^{16}$ She carries herself like Srikandi, and flaunts her martial skill, which is very exciting for her husband, from whom she takes no nonsense. Other wives are also on the campaign. The Ngurawan forces conquer part of Bali (apparently intending to capture noble ladies). They send envoys to the ruler, who is actually hiding in the inner palace while the public reception court is presided over by a substitute king! The real king of Bali is pining over the fact that Panji Asmarabangun is apparently dead, drowned in the middle of the ocean, while he, the king, has been awaiting for him for such a long time and has prepared many noblewomen for him. The king of Bali described as sakti but not honest, and clever at keeping secrets. Raden Gunungsari arrives with troops. He has had many adventures and many wounds. He was told in a dream that if he wanted to find what he sought he should serve under an outstanding commander who was conquering Bali, RT Kelana Jayakusuma. What he is seeking is Dewi Sekartaji, and also "Marabangun" (namely Panji). Jayakusuma tells him to sit with Gunungsari and ask forgiveness for his wrongdoing. Gunungsari's sister Sekartaji has vanished after their father was unfairly angry with her. Jayakusuma is thought to have died in battle, and the Putri Cemara is told to retreat but resolves either to find him or to follow him in death. Next we learn that Dewi Ragilkuning has been serving the king of Bali disguised (thanks to Batara Bayu) as a man - dat is Patih Jayaasmara. He got this job after killing a big snake that had attacked the king. The disguised Dewi Ragilkuning was recognized by a small beauty spot which was covered by her hair. She is the sister-in-law of the Putri Cemara and the sister of Sastramiruda ${ }^{17}$. She is now renamed Dewi Ekawarna. Next the Ngurawan forces defeat the Balinese army.

Among the surrendering commanders are the Adipati Bandayuda, Bupati Lumajang, and Bupati Pajarakan; also Raja Sidapaksa and Raja Balambangan. ${ }^{18}$ The Putri Bandayuda is also there, vowing to share in death or victory.

\footnotetext{
${ }^{14}$ Serat Panji mBedah Nagari Bali 1979.

${ }^{15}$ Serat Panji mBedah Nagari Bali (1979: 55-58).

${ }^{16}$ Serat Panji mBedah Nagari Bali $(1979: 41,43)$.

${ }^{17}$ Serat Panji mBedah Nagari Bali (1979: 71-75).

${ }^{18}$ Serat Panji mBedah Nagari Bali (1979: 77).
} 
Next comes a scene where the king of Bali is playing chess with his three [presumably favourite] wives - they get money if they win, he gets kisses if he does, and he wins.

But meanwhile, while RT Kelana Jayakusuma was away attacking the king of Bali, turmoil broke loose in Java in his absence ...

The Putri Cemara rounds up many captured noblewomen and presents them to her husband. Tumenggung [Jayakusuma] feels affected by an enchantment devised by the king of Bali, who is very daring with arrows, pikes, rifles, and kris. The beauty of Tumenggung Jayakusuma makes the king of Bali think he resembles the Prince of Jenggala "yang hilang terbawa angin" (gone with the wind).

Two gods, Sangyang Candra and Sangyang Narada, who appear to have been given the task of bathing the widadari, which they do in a playful spirit, are taking about the pertemuan (wedding meeting) of a noble couple in Bali. Narada descends to Bali, and meets the ruler. He advises him to submit to Tumenggung Jayakusuma because the prince [of Jenggala, the invincible warrior] is dead. Now the king of Bali reveals that he is actually the princess of Kediri who has changed form to wander around looking for Panji Asmarabangun. The princess-disguised-as-king now meets Tumenggung [Jayakusuma] who has a tanda "toh" on his lip exactly like Raden Inu Kertapati, Prince of Jenggala. ${ }^{19}$ The disguised Panji's wooing of the raja Bali who is actually none other than Dewi Sekartaji Galuh Candrakirana of Kediri is described. ${ }^{20}$ Narada says Panji must take her back to Kediri for their marriage: if they do it elsewhere, that state will be destroyed and even heaven will be shaken. ${ }^{21}$ Meanwhile Kediri has been conquered by a female ruler, who wants Candrakirana to marry to her son Bambang Sutirta. The king of Kediri is discussing the situation with the king of Bahuwarna (Ngurawan) and his warriors, and also with Ki Wasi Curiganata whom he asks to drive out the foreign occupying force. He however says he is only an ascetic from the mountains and cannot do it, only Raden Tumenggung [Jayakusuma] can. The king of Kediri doesn't know anyone of that name; it is said that R. Tumenggung [Jayakusuma] is said to be of Dayak origin. Then the princess of Jenggala offer to drive out the foreign army. It seems to them that Ki Wasi Curiganata looks very like Pangeran Nila Prabangsa. ${ }^{22}$ The queen is talking with the king of Nusatembini (which is sabrang, namely outside Java), called Raja Rukmaresi. They deduce that the raja of Daha has taken refuge with Ki Wasi Curiganata and they plan to capture him and the raja of Ngurawan and carry off Candrakirana. They send an army of women led by Adipati Sokadana who is a Banjarese/Melayu Bugis. These female soldiers are sakti because they were conceived in transcendental meditation (semadi). Bambang Sutirta has been chosen to marry Sekartaji. ${ }^{23}$

\footnotetext{
${ }^{19}$ Serat Panji mBedah Nagari Bali (1979: 2/25).

${ }^{20}$ Serat Panji mBedah Nagari Bali (1979: 2/26-27).

${ }^{21}$ Serat Panji mBedah Nagari Bali (1979: 2/28, 2/39).

${ }^{22}$ Serat Panji mBedah Nagari Bali (1979: 2/51).

${ }^{23}$ Serat Panji mBedah Nagari Bali (1979: 2/54-55)
} 
Ki Wasi Curiganata is doing heavy semadi, the effects of which are felt in heaven, so that Narada descends and sees that Ki Wasi Curiganata is his brother, Ki Prabangsa. Ki Wasi Curiganata denies it but he has the tahi lalat ("fly dropping" mark) that gives him away. ${ }^{24}$ Now the story shifts to the king of Singasari. His troops attack and defeat the Tawanggantungan troops, whose raja is concealed in a palanquin [tandu jempana]. He tells his son to go back and win but not to kill any of the Singasari people or the Kediri and Ngurawan princes because they are the beloved of the gods. ${ }^{25}$ They put to fight the ruler of Singasari and all his queens and occupy his kraton. R. Tumenggung Jayakusuma is at Banonbang, where he has had to stay a long time because Ki Menak Prasanta (who is related to Putri Cemara) has dysentery. In fact his illness is caused by missing his wife Dewi Kanistren, who was left behind in Jenggala. Dewi Surengrana is playing chess with the beautiful women, only the Adipati often wins against her. All the wives are asked for medicine to cure Ki Prasanta, now unconscious. Various remedies are proposed. Then a messenger comes announcing the occupation of Kediri by king Rukmaresi of Nusatembinii. Undhakan Sastramiruda asks about Nawang Wulan. ${ }^{26}$ Now comes a messenger, Raden Banyakwulan, sent by the king of Singasari announcing that the king has left the kraton after being attacked by the ruler of Tawanggantungan. Back at Singasari, Raden Banyakwulan is asked how he went. He explains that R. Tumenggung Jayakusuma is resting at Prabalingga, since his journey is made difficult by the number of his wives; then he arrives at Gunung Darawati. ${ }^{27}$ A description of Dewi Nawangwulan's beauty follows. The king of Singasari looks at Tumenggung Jayakusuma and thinks how very like he is to the Prince of Jenggala, who died when he went to Keling [South India]. A battle ensues against the forces of Tawang Gantungan, many of whom are killed. The princes report their losses and are asked who has done the damage. The answer is, a warrior from Ngurawan, called Tumenggung Jayakusuma, who has returned from conquering Bali. The man in the jempana smiles and gives thanks that the Prince of Jenggala is still alive. The Tawang Gantungan princes go to war. After his companions are captured, Jayakusuma himself advances to the battlefield, saying, Come on, enemy warriors! I am Jayakusuma, the chosen warrior famed across the world.

It is said that the people of Tawang Gantungan are treated equally and given food and drink, which is why they are daring in battle.

Jayakusuma undertakes nyepi/bersemadi (ascetic practice). He is visited by Sang Resi Kanekaputra who says that only he is the beloved of the gods, and asks what he wants.

It appears that ruler of Tawang Gantungan is actually Ki Prasanta's wife Dewi Kanistren, who after wandering around for some time was visited by

\footnotetext{
${ }^{24}$ Serat Panji mBedah Nagari Bali (1979: 2/58-59).

${ }^{25}$ Serat Panji mBedah Nagari Bali (1979: 2/61).

${ }^{26}$ The widadari descended from heaven who in Javanese Babads is the ancestress of the kings of Java.

27 Serat Panji (1979: 2/70).
} 
Bagawan Kanekaputra and told that if she wanted to find her husband she should conquer Singasari. Ki Prasanta recovers and it transpires that Dewi Kanistren is actually Jayakusuma's elder sister who was given to the Patih to be brought up as his child. Dewi Surengrana enquires of Dewi Kanistren about a man's skill in lovemaking. ${ }^{28}$ The ruler of Singasari is invited to return to his kraton. He gives his daughter Nawang Wulan to Jayakusuma, along with other Singasari noblewomen. Preparations are made for the return to Daha. ${ }^{29}$ The ruler of Singasari provides some troops for Kediri. At that time the ruler of Kediri is having a discussion with his younger brother the ruler of Ngurawan, and has called Ki Wasi Curiganata. Raden Gunungsari arrives, and is embraced by his father the king. He is told that his ayunda [Sekar Taji?] was asked by a raja from Nusatembini to marry him, but didn't want to, leading to war..$^{30}$ Now it is revealed that R. Tumenggung Jayakusuma - still struggling along the route with his many wives - is actually Raden Panji Asmarabangun. ${ }^{31}$ The king of Kediri asks him when he is going to take the Daha capital and warns him that the enemy is very sakti. That night the heroic Panji satisfies all the putri and then they set out for the encampment of the Nusatembini force, where the extremely sakti queen Raja Rukmaresi is performing semadi. Along comes Jayakusuma disguising himself as Batara Kamajaya; whereupon the queen tells him she is actually not a woman but is Sang Brahmanasakti, formerly known as Panji Sekar Dhanyang Prawita. The only one she fears is R. Panji Hino Kertapati from Jenggala. The one disguised as a god tells her that Panji has drowned. This news is greeted with joy by his rival who says he will now get Sekar Taji, and carry off the ruler, and ravish all his wives. ${ }^{32}$ Follows an erotic episode concerning two servants baring their breasts and asking the gods for good-looking husbands. ${ }^{33}$ Next comes a description of the Prince of Jenggala going to battle. On the enemy side, Danyang Prawita is no longer in the form of a woman. The Jenggala troops use a siasat (stratagem) called burung pipit, attacking together. The overseas troops - which include troops from Manila - are completely defeated. ${ }^{34}$ (Raja Rukmaresi is now dressed as a man, not a woman.) Rukmapada and Rukmawanda [his sons?] are killed in battle. Eventually Jayakusuma is told that the Raja Nusa Tembini has descended alone to the field. Jayakusuma mounts his horse and goes off to fight him, escalating his magical power (kesaktiannya) to its peak, to finish the conflict. He uses a supernaturally powerful arrow. The king and all his army are wiped out by a great wind. Only the troops of Kediri, Bali, Ngurawan, and Singasari are left on the battlefield..$^{35}$ Now, finally, it is revealed that Jayakusuma is actually Raden Panji Hino Kertapati, the prince of Jenggala.

\footnotetext{
${ }^{28}$ Serat Panji (1979: 2/86-88).

${ }^{29}$ Serat Panji (1979: 2/88-900).

${ }^{30}$ Serat Panji (1979: 2/92).

${ }^{31}$ Serat Panji (1979: 2/93).

${ }^{32}$ Serat Panji (1979: 2/96).

${ }^{33}$ Serat Panji (1979: 2/98).

${ }^{34}$ Serat Panji (1979: 2/101).

${ }^{35}$ Serat Panji (1979: 102-103).
} 
Everyone is very happy and Panji enters the kraton where, finally, he meets his wife Dewi Sekar Taji. Great celebrations follow. ${ }^{36}$

In this text, there is a sense of kinship and shared culture between the Javanese and Balinese and their going to war is due to a misunderstanding rather than deliberate aggression. All is amicably resolved. Nevertheless, here too the Javanese are the superior power, and the king of Bali is appropriately respectful.

Panji stories in modern Javanese show noticeably more awareness of the wider ("Indonesian" and even Southeast Asia) context than those in Middle Javanese. Banjarese, Dayaks, Melayu, Bugis, Makassarese, and even people from Manila now make an appearance. However, they are by no means seen as the equal of Javanese, and often have to be forcibly brought into line and taught to behave. One of Pakubuwana IV's Panji stories actually has a sketch of a very barbaric-looking Makassarese. ${ }^{37}$ Other Indonesian polities notably the Balinese are partners/allies of the Javanese, but not equals. The extreme Javanese chauvinism and contempt for other polities and cultures of these Modern Javanese stories meant that they could never have a significant Indonesian role in the post-colonial period. It was necessary to adopt a less hierarchical language, Malay, and more inclusive ideologies like Pancasila democracy, which had, understandably, much greater appeal.

And in Java itself, the elite seems to have become committed to views of this world and the next in which Panji played no part.

\section{A COURT WORLD DIFFERENTLY IMAGINED: YASADIPURA II AND DiPANAGARA YASADIPURA II}

Court writings reveal great changes in the court world and its ideologies since Panji's heyday as royal exemplar, and suggest that by the early nineteenth century new ways of seeing and analysing the world had developed. Two key texts revealing these changes are the Sasana Sunu, the great Modern Javanese work on governance written by the Surakarta court pujangga Yasadipura II (1756-1844), ${ }^{38}$ which provides guidance to the priyayi (the governing elite) concerning correct and incorrect behaviour in all aspects of their life, from manners and deportment to the exercise of governmental authority; and the autobiography of Dipanagara, the Yogyakarta prince and leader of the Java War (1785-1855) the last major Javanese war against the Dutch and their allies. Both of them reveal quite a lot about major changes taking place at the Javanese courts.

The Sasana Sunu attests to the emergence of what might be called a bureaucratic polity. It gives extensive guidance to the priyayi, the bureaucratic elite. In doing so it provides a picture of a very different from the royal court of Wangbay Wideya. It does not have a central hero, a single heroic male,

\footnotetext{
${ }^{36}$ Serat Panji (1979: 2/104).

${ }^{37}$ Panji Sekar 1979.

${ }^{38}$ Florida (1995: 258).
} 
whose personal qualities guarantee the continued existence and welfare of the state. Rather, it is a work of instruction for young men who would go on to actually run the court and principality of Surakarta. It represents perhaps the supreme codification of the highly buttoned-up, iron discipline of Java's bureaucratic elite. (This self-discipline extends to all areas, and includes an extraordinarily detailed array of prescriptions and proscriptions pertaining to sitting, standing, lying down, addressing people of various categories, as well as correct moral and social responses to different contingencies.)

Let us turn to its advice to priyayi holding official positions. It says that they should maintain law and order, know the ways of farmers, and set up a mosque and see that people attend, because strong ibadah ('to follow the commandments of Allah') will decrease gambling and opium-smoking. Thus, the mosque is seen as having the same virtue-maintaining role as was traditionally played by the English church.

The priyayi should also refrain from taking any of the zakat and fitrah; build a fence around the village; and maintain the local adat and not set up their own adat. They should remember that poverty is the root of crime. Yasadipura's position on the importance of both moral character and economic situation in giving rise to crime is an opinion that one might think more likely to be that of an Englishman of the eighteenth-nineteenth century than that of a Javanese from that period. ${ }^{39}$ We are in a different thought world from Wangbay Wideya, a bureaucratic state with ascetic functionaries practising restraint, politesse, correctness and a bit of social welfare.

Yasadipura gives a fascinating definition of a key legitimizing factor for the ruler and the governing elite: wahyu. This highly desirable thing is in contemporary usage usually regarded as a sort of supernatural blessing (for instance, President Suharto was widely said before his fall to have "lost" the wahyu, which he had presumably previously received). But in nineteenth century Javanese usage it is rather a sort of bank account of virtue that is increased or decreased by good or evil deeds. A particular example of the latter is taking food from the mouths of the poor, who Yasadipura says, have so little and whose life is so hard. Wahyu is like a clear star; if asked to be party to a dirty deed it becomes disturbed and angry and then flees, because there is no lack of places for it to perch. It will seek a heart that is pure and wise, fortunate and sage, for there it will be nurtured. To keep your wahyu is difficult but becomes easier with practice. Good deeds are a part of a shining wahyu, the sign of God's love. Priyayi are also advised to associate with those who may not be clever but are charitable to the poor and needy. And they should not have fine houses.

Such discourses on how wahyu may be won or lost clearly indicate that aristocratic claims to rule were considered to be based on virtue and moral conduct, and that if these were lacking a decline in worldly position would inevitably follow.

Javanese religion and ethics were classified by court writers into the "left-

\footnotetext{
${ }^{39}$ See for example Gilbert Geis 1955.
} 
hand" (Indic) and "right-hand" (Islamic) branches. Court authors produced versions of texts from both. The Taj us-Salatin, attributed to Yasadipura I, has even more stringent "performance indicators" than the Sasana Sunu. It depicts the king as the servant, not lord, of his people and expects him to undertake "menial" tasks such as going out at night in disguise carrying sacks of food for the unfortunate.

In conclusion, it is hard to see how all this emphasis on the absolute necessity for those in the business of government to take care of the tijang alit (lower-class people), and the consequences of neglecting to do so can have failed to affect the expectations of the populace concerning what they had a right to expect. Furthermore, the supreme requirement that justice be done seems to have been accepted by ruler and ruled. The Sasana Sunu is a proponent of responsible government, and rather Weberian rational bureaucracy. It provides a manual for training the priyayi that does not conform to the Panji story emphasis on the martial and the aesthetic abilities as the key qualities of royalty and their servants. Rather, it promotes restraint, correctness, politesse and attention to social welfare - not very Panji-like qualities.

\section{DIPANAGARA'S MYTHIC WORLD}

Just as Wangbay Wideya sets out the claims of the eponymous hero to the throne, so Dipanagara, who also has such claims, sets out these in his autobiography. The warrior ethos of the Wangbay Wideya is continued by Dipanagara, but the supernatural world that he inhabits and describes is very different.

Dipanagara provides a narrative of his life clearly stating his values, beliefs, and motivation. ${ }^{40}$ This personal account is both rare and extremely interesting. Dipanagara makes his claim to rule - in fact to take the throne from the incumbent - on the basis of two different things: a divine mandate; and custodianship of what we might perhaps summarize as the "rights of the population". So he comes across as a surprising blend of the full-blown ecstatic, visionary warrior and the careful steward of the budget and the limits of taxation to be paid by the common people.

Dipanagara's account does have a notable religious dimension, but it is very different from that of the Hinduized Wangbay Wideya, blending Islamic and indigenous Javanese beliefs. It is a mythic world, but Panji is absent from it.

His divine mandate is demonstrated in Dipanagara's account of a number of supernatural visitations. There is a visit from the wali Sunan Kalijaga announcing that Dipanagara would be a king; and - of equal or even greater importance - a visit from Ratu Kidul, the Queen of the South Seas, one of the two great indigenous goddesses who legitimise Javanese kings. Dipanagara also hears a voice telling him he would play the chief part in a forthcoming "disturbance", and on return to the mundane world finds that he has been given the arrow Sarotama, which in Hindu mythology belongs to Arjuna. Finally, he meets the Ratu Adil, the "Just King", who tells Dipanagara that he

\footnotetext{
${ }^{40}$ Ann Kumar 1972.
} 
has to be his soldier, and that his, Dipanagara's, mandate is the Koran. "Adil" is an Arabic loanword, and it is significant that this particular word was not just borrowed into Javanese but spread like wildfire. Dipanagara - who has already said that it is better to be a poor and lowly santri than to be involved in court affairs - protests that he is no warrior. But the Ratu Adil insists and, surrounded by other supernatural phenomena, Dipanagara agrees to obey his command. So he is representing himself as the chosen one of the Ratu Adil, who, he claims, appeared to him.

But his supernatural mandate from the Ratu Adil is only part of Dipanagara's justification for criticizing and eventually rebelling against the government. Consistent with the strong positive value Java's elite culture placed on restraint and even asceticism, he condemns the ruler for eating and drinking and merry-making in the Dutch fashion. But most strongly of all he is committed to reducing the burdens on the common people, and thus outraged by the appointment of "Collectors", describing this as a piece of absolute villainy which will certainly harm them. What, he asks, is the salary of the Collectors, and how many of them are there? And what buildings will be provided for their daily meetings? Eventually, he succeeds in persuading the Sultan not to appoint these Collectors.

He also says that in the time of his late father he asked that all the gunung ${ }^{41}$ should be dismissed, on account of the burden they were to the common people. He had proposed to substitute the corvée services and the money from the tolls in all the ports, which he claims should be more than enough so that there would be no shortage of funding. In other passages he raises objections to the way tolls were levied, which we know from other sources undeniably constituted a major burden and grievance.

Dipanagara claims that he had asked that the government of the villages should return to the arrangements existing in the reign of his great-grandfather. He says that his revered father had agreed to this, stipulating that this be done in one year's time. This was intended to fill the state coffers since the finances were quite depleted. Before a year had passed however, his revered father passed away. One cannot imagine Panji (Illustration 1), like Dipanagara a Crown Prince (or claimant to be one), investigating such prosaic things as buildings, meetings, bueaucrats, taxes and tolls.

Taken together, these statements and claims made by Dipanegara add up to a "government based on the well-being of the common people" mandate, which is as important as the blessings of divinities. All this interest in the practicalities of government, taxation and administration is an almost Benthamite approach - again, very far indeed from any Panji text. And it is very difficult indeed to imagine Dipanagara writing Panji stories, let alone playing the role of Panji in a court dance-drama.

${ }^{41}$ The gunung were police officials with some judiciary powers (for levying fines, etcetera) (Kumar 1972: 81). 


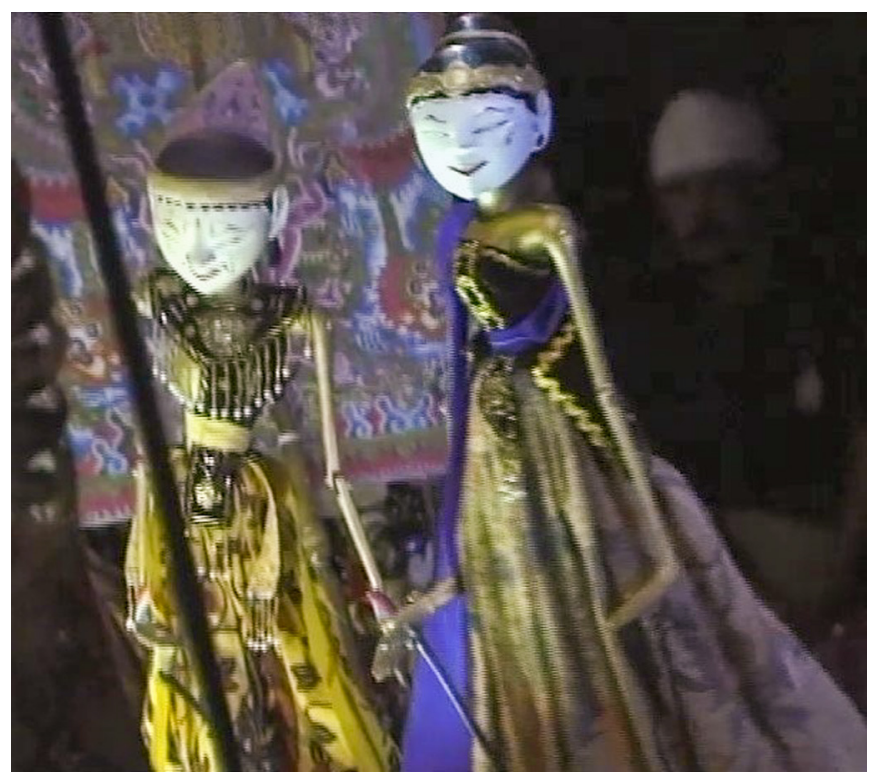

Illustration 1. Panji (left) and consort puppets in a West Javanese wayang golek play from the 1990s. (Photograph by the author).

Apart from these works by Yasadipura II and Dipanagara, there seem to have been didactic works in circulation for a considerable period of time that set out the "performance indicators", deriving from indigenous, Indic, and Islamic sources, by which rulers were judged. The stock phrase used to describe the reign of a good king is murah sandang lan pangan ('clothes and food were cheap'). (This is a much more mundane and materialistic evaluation than, say, the Malay emphasis on not shaming subjects of the ruler.) Kings were also conventionally grouped into three categories, namely nisța (low, despicable), madya (middling), and utama (outstanding). The manuscript NBS 89 as part of the Surakarta manuscripts says that the utama king is one who dispenses justice and maintains the truth. Furthermore, the author says, the nisț king, who treats his subjects unjustly, will not be able to maintain his position, and his realm will fall into the hands of an outstanding king. This implies that a king, even though he be of divine descent, was not guaranteed to remain on the throne unless he treated his subjects justly. So both in Dipanagara's autobiography and in general social expectations there is no value placed on the glamour and accomplishment, let alone the sexual prowess, of Wangbay Wideya. Yet Panji retained a strong presence in Javanese society. In wayang, of which specific types such as wayang golek are devoted to Panji, and in topeng - performances of which were much commoner across Java than the more elaborate and expensive wayang ones - Panji remains the archetype of aristocratic and heroic masculinity. His aristocratic refinement is indicated by the fine features and downward gaze of the puppet portraying him. Warriors from outside Java are more brutish in appearance.

The Javanese courts were reduced to pathetic dependencies on Dutch 
favour after the defeat of the Java War in 1830, which might perhaps have brought about the demise of the apparently court-centric Panji stories. However, Ranggawarsita wrote a Panji story a generation later. ${ }^{42}$

But these were also popular outside the courts. An account of wayang gedhog performances by a Dutch observer around 1820 reveals how popular these Panji dramas were in Gresik. He lists the following performances: "Dandang Welis, Kudanarawangsa, angrene, angron akoong, magat-koong, prijembada, prowelas maroe, moerdaningkoong, Djaja koesoema, kalmendang dadang dewa and wahoe djaja" [names of some of the many different eponyms, characters, and episodes within the Panji corpus. Kuda Narawangsa for example is one of the alternative names of Candrakirana, Panji's beloved and consort: others are Sekartaji and Anggreni]..$^{43}$ The picture above (Illustration 1 ) is a still from a video of a wayang gedhog performance of the 1990s. ${ }^{44}$ Panji stories were the subject matter of the ancient and now probably extinct wayang beber performance using scrolls, and also of wayang klitik, ${ }^{45}$ which uses flat wooden puppets. These theatrical forms and, probably most importantly, the topeng dance troops, kept the Panji stories in circulation.

As might be anticipated, Panji stories were offensive to some Islamic sensibilities: see for a succinct and useful coverage https:// blogs.bl.uk/asianand-african/2015/06/panji-stories-in-malay.html.

\section{B. PANJI OVERSEAS}

As noted above, Panji tales are found not only in the Javanese literary tradition but also in Balinese and Malay, and on the Southeast Asian mainland in Thai, Lao, Khmer, and Burmese versions, where the hero-prince is known as Inao (after his main Javanese name, Raden Inu Kartapati). The Panji stories appear to have been translated into Malay at an early date, perhaps in the cosmopolitan port city of Melaka in the fifteenth century, and influences can be discerned in the Malay texts Sejarah Melayu and Hikayat Hang Tuah. Over a hundred different Panji stories in Malay are known, in numerous manuscripts, many originating from the northern peninsular states of Kelantan and Kedah where wayang (shadow puppet) stories were most popular. ${ }^{46}$

That Panji stories should have spread widely within Indonesia ${ }^{47}$ and the Malay world is not very surprising. What is surprising is that they have travelled so far outside the realm of Indonesian languages, to mainland Southeast Asia, where they have been rendered into quite different languages and undergone localization.

The Javanese and Malay Panji stories were introduced to the Thai court around the eighteenth century in the reign of King Barommakot in the late

${ }^{42}$ R.Ng. Ranggawarsita (1865), Serat Panji Jayeng Tilam.

${ }^{43}$ Kumar (1997: 136).

${ }^{44}$ Kumar (https:/ / dna-warrior-woman.net/).

${ }^{45}$ David Irvine (1996: 128-133).

${ }^{46} \mathrm{Https}$ // / blogs.bl.uk/asian-and-african/2015/06/ panji-stories-in-malay.html.

${ }^{47}$ The admiration and devout imitation of everything Javanese is nowhere more prominently displayed than in the Hikayat Banjar (see J.J. Ras 1968). 
Ayutthaya period. Based on the Panji stories they had heard, the two daughters of King Barommakot composed two Panji stories in to be performed as a Thai court dance drama or Lakhon Nai. The elder princess composed Dalang, while the younger princess composed Inao. Before these two Panji stories were composed and performed, the repertoires of the Thai court dance drama had been solely based on the Indian epics. The Panji stories Inao and Dalang were recomposed by King Rama I (1782-1809). The first is complete, but only seven episodes of the Inao survived. King Rama II (1809-1824) rewrote the Inao of King Rama I to add more literary beauty and to better serve as a Thai court dance drama. Among Thai audiences, the story of Inao is much more popular than that of Dalang, and has provided the inspiration for various works of literature, paintings, songs, performances, and even television dramas. ${ }^{48}$

But there is an even more surprising episode in the spread of the Panji stories. Javanese influence on Yayoi Japan has been revealed by DNA studies and by the significant number of Javanese loanwords in Old Japanese. Particularly prominent are loanwords related to technology - wet rice, metallurgy, swords, warehouses, fences, rice-mortars, plates, cloth, and baskets - as well as ideas of royalty and divinity, and of the divinity of royalty ${ }^{49}$. It seems likely that an early form of the Panji stories influenced a prototype of the great Japanese court romance, the Tale of Genji. ${ }^{50}$

Evidence from a number of fields indicates that Javanese influence must have occurred with the introduction of rice agriculture, metallurgy, royal courts, and other innovations in Yayoi Japan. This of course means that the Panji stories - in a specifically court not tribal form - are actually far older and more widespread than was ever previously suspected - and that the court society whose agenda and ideology they promote is too. This is, it need hardly be said, a major shift in our understanding of the historical evolution of Javanese society.

Even if we discount the alleged influence on Japan, the geographical reach and influence of the Panji stories is only rivalled by just one other court composition: the stories of Arthur and the knights of the round table. This, too, spread very far from its place of origin, though its attractions are very different from those of the Panji stories (erotic, humorous, and fantastic elements are notably absent). Like the Panji stories, the Arthurian romance has had an enduring exemplary character, into Victorian times and even later. No doubt for many complex reasons that it is impossible to investigate here, these two visualizations of the ideal aristocratic male have somehow outshone all others.

\footnotetext{
${ }^{48}$ Thaneerat Jatuthasri 2018.

${ }^{49}$ Summarized in Ann Kumar and Phil Rose 2000.

${ }^{50}$ See further Ann Kumar (2009: 147-157).
} 


\section{WORKS CITED}

Brakel-Papenhuyzen, Clara. 1992. "Of sastra, pènget and pratélan; The development of Javanese dance notation", Bijdragen tot de Taal-, Land- en Volkenkunde 148/1: 3-22.

Brakel-Papenhuyzen, Clara. 1993. "Character types and movement styles in traditional Javanese theatre", in: B. Arps (ed.), Performance in Java and Bali, pp. 59-72. London: School of Oriental and African Studies, University of London.

Florida, Nancy K. 1993. Javanese literature in Surakarta manuscripts; Manuscripts of the Mangkunegaran palace. Ithaca, NY: Cornell University Press. [SEAP Publications.]

Florida, Nancy K. 1995. Writing the past, inscribing the future; History as prophecy in colonial Java. Durham, NC: Duke University Press.

Geis, Gilbert. 1955. "Pioneers in criminology VII; Jeremy Bentham (1748-1832)", Journal of Criminal Law, Criminology, and Police Science 46/2: 159-171.

Irvine, David. 1996. Leather gods and wooden heroes; Java's classical wayang. Singapore: Times editions.

Jatuthasri, Thaneerat. 2018. "Inao of King Rama II; The transformation of the Panji stories into a masterpiece of Thai court drama literature", SPAFA Journal Vol. 2: 1-12. [Retrieved from: http:// www.spafajournal.org/index. php/spafajournal/article/view/576/602, accessed on 20-10-2019.]

Kumar, Ann. 1972. “Dipanegara (1787-1855)”, Indonesia 13 (April): 69-118.

Kumar, Ann. 1980. "Javanese court society and politics in the late eighteenth century; The record of a lady soldier", Indonesia 29 (April): 1-46.

Kumar, Ann. 1997. Java and modern Europe; Ambiguous encounters. Richmond, VA: Curzon.

Kumar, Ann. 2009. Globalizing the prehistory of Japan; Languages, genes, and civilization. London/New York: Routledge.

Kumar, Ann and Phil Rose. 2000. "Lexical evidence for early contact between Indonesian languages and Japanese", Oceanic Linguistics 39/2 (December): 219-255.

Panji Dadap. 1980. Panji Dadap; Pakubuwana IV, Susuhunan van Surakarta, 17681820. Translated by Sudibjo Z. Hadisutjipto and Abimanyu Wirasmi. Jakarta: Proyek Penerbitan Buku Bacaan Sastra Indonesia dan Daerah, Departemen Pendidikan dan Kebudayaan.

Panji Raras. 1978. Panji Raras; Pakubuwana IV, Susuhunan van Surakarta, 17681820. Translated by A. Hendrato. Jakarta: Proyek Penerbitan Buku Bacaan Sastra Indonesia dan Daerah, Departemen Pendidikan dan Kebudayaan. Panji Sekar. 1979. Panji Sekar; Pakubuwana IV, Susuhunan van Surakarta, 17681820. Translated by Yanti Darmono. Jakarta: Proyek Penerbitan Buku Sastra Indonesia dan Daerah, Departemen Pendidikan dan Kebudayaan.

Ranggawarsita, R.Ng. 1865. Serat Panji Jayeng Tilam; Kidung macapat babonipun saking Nagari Surakarta. Batavia: Lange en Co.

Ras, J.J. 1968. Hikajat Bandjar; A study in Malay historiography. The Hague: Martinus Nijhoff 
Rassers, W.H. 1959. Panji, the culture hero; A structural study of religion in Java. The Hague: Nijhoff.

Robson, S.O. 1971. Waybay Wideya; A Javanese Pañji romance. The Hague: Nijhoff. [Bibliotheca Indonesica 6.]

Serat Panji mBedhah Nagari Bali. 1979. Serat Panji mBedhah Nagari Bali. Edited and translated by Soenarko H. Poespito. Jakarta: Proyek Penerbitan Buku Sastra Indonesia dan Daerah, Departemen Pendidikan dan Kebudayaan.

Zoetmulder, P.J. 1982. Old Javanese-English dictionary. With the collaboration of S.O. Robson. Two vols. The Hague: Nijhoff. 